FINAL REPORT

U.S. Department of Energy

\title{
RESEARCH PROGRAM TO DETERMINE REDOX REACTIONS AND THEIR EFFECTS ON SPECIATION AND MOBILITY OF PLUTONIUM IN DOE WASTES
}

\author{
Principle Investigators: Gregory R. Choppin \\ Florida State University \\ and \\ Dhanpat Rai \\ Pacific Northwest National Laboratory \\ Grant Number:FG07-96ER14734 \\ Grant Project Officers: Carol Van Lente \\ Project Duration:09/10/1996 B 09/03/2000
}

Project Numbers: FSU 27623

PNNL RL3-SP-22 Task 14 
page number

I. Executive Summary 2

II. Research Objectives 3

III. Research Results 4

III-1 Importance of Organic Complexes of Pu(IV) Species 4

III-2 Thermodynamics of the $\mathrm{PuO}_{2}{ }^{+}-\mathrm{Na}^{+}-\mathrm{OH}^{\mathrm{B}}-\mathrm{Cl}-\mathrm{ClC}_{4}{ }^{\mathrm{B}} \mathrm{H}_{2} \mathrm{O}$ System: $\quad 6$ Use of $\mathrm{NpO}_{2}{ }^{+}$Pitzer Parameters for $\mathrm{PuO}_{2}{ }^{+}$

III-3 Plutonium with/without Reducing Agents $\quad 15$

$\begin{array}{ll}\text { IV. Details of Results } & 16\end{array}$

IV-1 Th(IV) Complexation with Citrate and EDTA 16

$\begin{array}{ll}\text { IV-2 Solubility Measurements of } \mathrm{PuO}_{2(\mathrm{am})} & 18\end{array}$

IV-3 $\mathrm{PuO}_{2}^{+}$Reduction by $\mathrm{H}_{2} \mathrm{O}_{2} \quad 20$

$\begin{array}{ll}\text { IV-4 Pu(IV) Oxidation by } \mathrm{MnO}_{2} & 23\end{array}$

$\begin{array}{ll}\text { IV-5 Pu(IV) Oxidation by } \mathrm{NaOCl} & 23\end{array}$

$\begin{array}{ll}\text { V. References } & 28\end{array}$

VI. Publications from this EMSP Grant 33

VII. Personnel Supported 34 


\section{Executive Summary}

Plutonium is one of the major contaminants at many DOE sites where plutonium containing solutions have been released to soils and sediments. Plutonium is present in the soils and sediments at half of the DOE sites and in the groundwater at even more of these. The plutonium-bearing wastes stored at DOE sites often contain organics (e.g., EDTA, NTA, DTPA) as residues from separation processes. The soils at these sites vary greatly in $\mathrm{pH}$, soluble inorganic and organic electrolytes, Eh, and plutonium concentration. This plutonium can be present in multiple oxidation states (III, IV, V, and VI) and, in these oxidation states, forms aqueous complexes of varying stability and solid phases of varying solubility. The dominant oxidation state in solid and in the aqueous phase may differ; e.g., $\mathrm{Pu}(\mathrm{IV})$ solids are in equilibrium with aqueous $\mathrm{PuO}_{2}{ }^{+}$. As a result, plutonium in these geologic matrices undergoes a variety of complex reactions which complicate its environmental behavior. These complexities in plutonium chemistry whereby a large variety of precipitation, dissolution, adsorption/desorption, and redox reactions control plutonium speciation and concentrations, result in the need for a rather large amount of reliable, fundamental data to predict Pu behavior in geologic media.. These data are also needed for evaluation of remediation strategies that involve removing most of the contaminants by selective methods, followed by in-situ immobilization of residual contaminants.

Two areas were studied during this EMSP project: 1) thermodynamic data for Th(IV) and $\mathrm{Pu}(\mathrm{IV})$ complexes of EDTA and for $\mathrm{Pu}(\mathrm{V})$ interactions with chloride; 2) kinetic data for redox reactions of $\mathrm{Pu}$ in the presence of common redox agents (e.g., $\mathrm{H}_{2} \mathrm{O}_{2}, \mathrm{MnO}_{2}$, and $\mathrm{NaOCl}$ ) encountered under waste disposal conditions. These studies are relevant to understanding Pu behavior in wastes disposed of in diverse geologic conditions (e.g., at the WIPP and YUCCA Mountain repositories and in contaminated sediments at many different DOE sites) and also for developing effective remediation strategies (e.g., processing of high level waste tanks).

During this 3 year period, reliable thermodynamic data for $\mathrm{Pu}(\mathrm{IV})$ complexes with EDTA and for $\mathrm{Pu}(\mathrm{V})$ with chloride were obtained (Rai et al. 2000a and 2000b). These studies, especially those with $\mathrm{Pu}(\mathrm{IV})$, have provided a methodology for studying $\mathrm{Pu}(\mathrm{IV})$ behavior where the concentration of the simple, hydrated ion, $\mathrm{Pu}^{4+}$ can be determined as this is needed for accurate measurement of equilibrium constants (Rai et al. 2000a). It was not possible in previous studies reported in the literature to determine reliably the concentration of $\mathrm{Pu}^{4+}$, even in very acidic conditions, due to hydrolytic interference and the lack of reliable hydrolysis constants. Our methodology can be used to study 
systems involving EDTA and other ligands, (e.g., DTPA, HEDTA, and NTA) which were used in separations and, consequently, are present in the wastes.

A number of studies (Nelson and Lovett 1978, Nelson et al. 1984, Bondietti and Trabalka 1980, Fukai et al. 1987, Choppin et al. 1986, Choppin and Stout 1989) have shown that Pu(V) is the dominant soluble Pu species in natural waters (Pacific Ocean, Irish Sea, Mediterranean Sea, Lake Michigan, Gulf of Mexico, and in alkaline freshwater ponds). Despite the reported stability of $\mathrm{Pu}(\mathrm{V})$ in these systems, little data are available for important $\mathrm{Pu}(\mathrm{V})$ reactions. Under this EMSP contract, we showed that thermodynamic data for $\mathrm{Np}(\mathrm{V})$ can be used to reliably predict $\mathrm{Pu}(\mathrm{V})$ behavior (Rai et al. 2000b). We also demonstrated the need for research on the effects of reducing agents generally present in geologic environments to reduce plutonyl species to the lower oxidation states (Choppin 1999). We have also studied the effect of $\mathrm{H}_{2} \mathrm{O}_{2}, \mathrm{NaClO}$, and $\mathrm{MnO}_{2}$ on the reduction of $\mathrm{Pu}(\mathrm{V})$ in this research period and have in the past studied the reduction kinetics of $\mathrm{U}(\mathrm{VI})$ and $\mathrm{Np}(\mathrm{VI})$ by organic compounds of environmental importance (Choppin and Rao 1992, Choppin 1991, Rao and Choppin 1991a, 1991b). In summary, these studies have yielded data to address redox reactions of plutonium in the presence of environmentally important agents (e.g. organic and inorganic oxidants/reductants).

\section{Research Objectives}

The stored USDOE tank wastes contain plutonium as well as organic co-contaminants (e.g., EDTA, NTA, DTPA) in alkaline media. Most of these organic contaminants strongly complex Pu and can make Pu(IV) (which is otherwise fairly insoluble) soluble and, therefore, mobile. However, reliable values for stability constants for these $\mathrm{Pu}(\mathrm{IV})$ complexes, which are necessary to predict $\mathrm{Pu}$ behavior in the presence of these organic ligands, are not available. In addition, if released to the environment by accidents, leaks, etc, the plutonium would be in complex geologic matrices which vary greatly in $\mathrm{pH}$, soluble inorganic and organic electrolytes, Eh, and plutonium concentration. Plutonium in these geologic matrices can undergo a variety of complex reactions that control its environmental behavior. Because of the complexities in plutonium chemistry (four different oxidation states that show differing behavior) and in disposal conditions where a large variety of precipitation/dissolution, adsorption/desorption, and redox reactions can control plutonium oxidation states and concentrations, there is a pressing need for a fundamental approach to obtain data capable of reliably predicting plutonium behavior in these extremely complex and diverse matrices. These data are also needed for remediation strategies which 
involve removing the contaminants by selective leaching followed by ex-situ treatment for removal or insitu retention of contaminants for immobilization.

To contribute to the development of a fundamental model for reliably predicting the geochemical behavior of Pu in diverse geologic environments, the emphasis of these studies was placed on only the important aspects of Pu chemistry for which reliable data are not available. Therefore, our studies dealt with developing 1) thermodynamic data for Pu(IV)-EDTA complexes and methodology for developing thermodynamic data for other ligands, such as NTA and DTPA, that strongly complex Pu(IV), 2) thermodynamic data for $\mathrm{Pu}(\mathrm{V})$ systems and demonstration that thermodynamic data for $\mathrm{Np}(\mathrm{V})$, an analog for $\mathrm{Pu}(\mathrm{V})$, can be used to describe $\mathrm{Pu}(\mathrm{V})$ behavior, and 3) fundamental data on $\mathrm{Pu}$ oxidation state transformation reactions in the presence of environmentally important oxidants and reductants.

\section{Research Results}

$\underline{\text { III-1 Thermodynamic Model for the Solubility of } \mathrm{PuO}_{2}} \underline{(\mathrm{am}) \text { in the Aqueous } \mathrm{Na}^{+}-\mathrm{H}^{+}-\mathrm{OH}^{-}-\mathrm{Cl}^{-}-\mathrm{H}_{2}} \underline{\underline{\mathrm{O}}-}$ ehtylenediaminetetraacetate System

Soils contaminated with plutonium are present at a number of USDOE sites (e.g., Oak Ridge, Hanford, Savannah River, Los Alamos, Rocky Flats, the Nevada Test Site) and are of concern due to the long half-life and high toxicity of plutonium (ORNL 1993, Riley et al. 1992)..

Ethylenediaminetetraacetic acid $\left(\mathrm{H}_{4}\right.$ EDTA), which was co-disposed with radionuclides at several sites, has been reported to enhance the solubility and transport of $\mathrm{Pu},{ }^{60} \mathrm{Co}$, and other radionuclides in groundwater at Oak Ridge, Chalk River, and Maxey Flats (Riley et al. 1992, Cleveland and Rees 1981, Means et al. 1978, Champ and Robertson 1986, Killey et al. 1984). Despite the reported impact of organic complexants on Pu solubility and mobility in geologic environments, limited reliable, experimental thermodynamic data exist on complexation with these ligands (Foreman and Smith 1957a and 1957b, Cauchetier and Guichard 1973). For example, the reported equilibrium constants for $\mathrm{Pu}(\mathrm{IV})$ formation of PuEDTA(aq) vary over nine orders of magnitude. Moreover, these values are based on data obtained in relatively acidic conditions $(\mathrm{pH}<4)$, which may not be applicable to the range in $\mathrm{pH}$ values expected in most environmental conditions. Foreman and Smith (1957b) reported a difference of over seven orders of magnitude between the equilibrium constants they obtained for PuEDTA formation at $\mathrm{pH} 3.3(\log \mathrm{K}$ of 17.1$)$ and in $1.0 \mathrm{M} \mathrm{HNO}_{3}(\log \mathrm{K}$ of 24.2). This value was later revised by Klygin et al. (1959) to 26.15 and by Krot et al. (1962) to 26.75 because the authors did not 
consider $\mathrm{H}_{5}$ EDTA $^{+}$and $\mathrm{H}_{6}$ EDTA $^{2+}$, which are important in these acidic solutions. Our studies, described later, show that none of these values are applicable to the range of $\mathrm{pH}$ values encountered in geologic environments.

A major difficulty in calculating reliable values of complexation constants for strongly complexing ligands [e.g., EDTA, DTPA, and NTA] by the techniques (spectrophotometric, polarography, and ion exchange) and $\mathrm{pH}$ values used in past studies is that the concentration of $\mathrm{Pu}^{4+}$ needed to calculate these constants is very difficult to measure reliably. This is due to the very strong hydrolysis of $\mathrm{Pu}^{4+}$ which is further complicated by the redox behavior of Pu. It is relatively easy to control plutonium in the highest, $\mathrm{Pu}(\mathrm{VI})$, or lowest, $\mathrm{Pu}(\mathrm{III})$, oxidation states by adding strong oxidizing or reducing agents but it is more difficult to maintain it in the $\mathrm{Pu}(\mathrm{IV})$ and $\mathrm{Pu}(\mathrm{V})$ states, especially under conditions relevant to geologic environments.

Some of the major difficulties encountered in the past can be overcome by studies of the solubility of plutonium in equilibrium with a $\mathrm{Pu}(\mathrm{IV})$ solid of known solubility product as this can provide reliable values of $\mathrm{Pu}^{4+}$ concentration as a function of $\mathrm{pH}$. We, therefore, studied the solubility of $\mathrm{PuO}_{2}(\mathrm{am})$ in solutions of $0.001 \mathrm{M}$ and $0.0001 \mathrm{M}$ total EDTA concentration for $\mathrm{pH}$ values ranging form 1 to 13.5. Another set of experiments were done at a $\mathrm{pH}$ of approximately 9 and with EDTA concentrations ranging from 0.00001 to $0.093 \mathrm{M}$. The solubility studies were carried out as a function of time. The oxidation states were determined by x-ray absorption near edge spectroscopy and solvent extraction.

\section{Significant Results}

The comparison of the experimental solubility with the predictions based on literature data (Cauchetier and Guichard 1973) showed that the predicted concentrations are orders of magnitude lower (e.g. at $\mathrm{pH} \mathrm{8,} \mathrm{the} \mathrm{difference} \mathrm{is} \mathrm{approximately} \mathrm{six} \mathrm{orders} \mathrm{of} \mathrm{magnitude)} \mathrm{and} \mathrm{this} \mathrm{difference}$ increases with the increased $\mathrm{pH}$. This indicated that the existing models were inadequate to represent complexation behavior of $\mathrm{Pu}(\mathrm{IV})$ with EDTA at $\mathrm{pH}$ values $>4$ (Figure 1). Our data were interpreted using the Pitzer ion-interaction model (Pitzer 1991) that is applicable to dilute as well as concentrated electrolytes. Our model was developed based on the solubility of $\mathrm{PuO}_{2}(\mathrm{am})$ at $0.0001 \mathrm{M}$ EDTA concentrations and as a function of $\mathrm{pH}$. The assumption of $\mathrm{Pu}(\mathrm{OH})_{\mathrm{x}} \mathrm{EDTA}$, instead of PuEDTA(aq), in the model successfully simulated the observed plutonium concentrations as a function of $\mathrm{pH}$ in the entire $\mathrm{pH}$ region (Figure 1). This is consistent with the absence of a significant formation of PuEDTA in favor of the ternary complexes $\mathrm{Pu}(\mathrm{OH})_{\mathrm{n}} \mathrm{EDTA}^{-\mathrm{n}}$. 
The reliability of the model developed from the data for $\mathrm{PuO}_{2}(\mathrm{am})$ equilibrated with $0.0001 \mathrm{M}$ EDTA at different $\mathrm{pH}$ values for 7 days, using the modeling parameters given in Tables 1 and 2, was tested against $\mathrm{PuO}_{2}(\mathrm{am})$ solubility in $0.001 \mathrm{M}$ EDTA over a wide range in $\mathrm{pH}$ values and against EDTA concentrations ranging from very low to $0.093 \mathrm{M}$ at a fixed $\mathrm{pH}$. Close agreement between the experimental and predicted $\mathrm{Pu}$ concentrations in these different sets indicates that this model is consistent with the experimental data over the full range of conditions. The model included $\mathrm{Pu}(\mathrm{OH}) \mathrm{EDTA}^{-}, \mathrm{Pu}(\mathrm{OH})_{2} \mathrm{EDTA}^{2-}, \mathrm{Pu}(\mathrm{OH})_{3} \mathrm{EDTA}^{3-}$, and the Pitzer ion-interaction parameters for the bulk electrolyte ions and for the different EDTA species (Table 2). These modeling parameters provide $\log \mathrm{K}^{0}$ values for the $\mathrm{PuO}_{2}(\mathrm{am})$ dissolution reactions of $21.58,15.92$, and 6.95 for the formation of $\mathrm{Pu}(\mathrm{OH}) \mathrm{EDTA}^{-}, \mathrm{Pu}(\mathrm{OH})_{2} \mathrm{EDTA}^{2-}$, and $\mathrm{Pu}(\mathrm{OH})_{3} \mathrm{EDTA}^{3-}$, respectively according to the reaction $\left[\mathrm{PuO}_{2}(\mathrm{am})+\mathrm{EDTA}^{4-}+(4 \mathrm{~B} \mathrm{x}) \mathrm{H}=\mathrm{Pu}(\mathrm{OH})_{\mathrm{x}} \mathrm{EDTA}^{-\mathrm{x}}+(2-\mathrm{x}) \mathrm{H}_{2} \mathrm{O}\right]$. The combination of the log of the solubility product value of $\mathrm{B} 56.85$ (Rai 1984) for $\left[\mathrm{PuO}_{2}(\mathrm{am})+2 \mathrm{H}_{2} \mathrm{O}=\mathrm{Pu}^{4+}+4 \mathrm{OH}^{-}\right]$combined with the equilibrium constant of the above reaction provides $\log \mathrm{K}^{0}$ values of $36.44,44.78$, and 49.80 for the formation of $\mathrm{Pu}(\mathrm{OH}) \mathrm{EDTA}^{-}, \mathrm{Pu}(\mathrm{OH})_{2} \mathrm{EDTA}^{2-}$, and $\mathrm{Pu}(\mathrm{OH})_{3} \mathrm{EDTA}^{3-}$, respectively, according to the reaction $\left[\mathrm{Pu}^{4+}+\mathrm{xOH}^{-}+\mathrm{EDTA}^{4-}=\mathrm{Pu}(\mathrm{OH})_{\mathrm{x}} \mathrm{EDTA}^{-\mathrm{x}}\right]$. The different complexes are dominant in different $\mathrm{pH}$ regions.

The stability constants from this EMSP study were used to predict $\mathrm{Pu}(\mathrm{IV})$ behavior in the presence of EDTA and the results indicated that EDTA complexes of $\mathrm{Pu}(\mathrm{IV})$ are not important in the high-level waste tanks as the calculated concentrations in the presence of $0.001 \mathrm{M}$ EDTA are extremely low due to hydrolytic competition at the high $\mathrm{pH}$ values of the wastes. We have developed, also, a method for reliably determining $\mathrm{Pu}(\mathrm{IV})$ stability constants with other strongly complexing ligands such as HEDTA, DTPA, and NTA.

A manuscript based on the data developed in this study was prepared and is in press in Radiochimica Acta. (Rai et al 2000a).

$\underline{\text { III-2. Thermodynamics of the } \mathrm{PuO}_{2}{ }^{+}-\mathrm{Na}^{+}-\mathrm{OH}^{\mathrm{B}}-\mathrm{Cl}^{\mathrm{B}}-\mathrm{ClO}_{4}{ }^{\mathrm{B}}-\mathrm{H}_{2}} \underline{\mathrm{O}}$ System: Use of $\mathrm{NpO}_{2}{ }^{+}$Pitzer $\underline{\text { Parameters for } \mathrm{PuO}_{2}} \underline{ \pm}$

Reliable thermodynamic data for all the oxidation states of plutonium are required to develop comprehensive models for prediction of its behavior in different environments. The difficulty in obtaining reliable thermodynamic data for $\mathrm{Pu}(\mathrm{V})$ due to its redox and/or disproportionation reactions in aqueous systems has resulted in very limited data for $\mathrm{Pu}(\mathrm{V})$ 


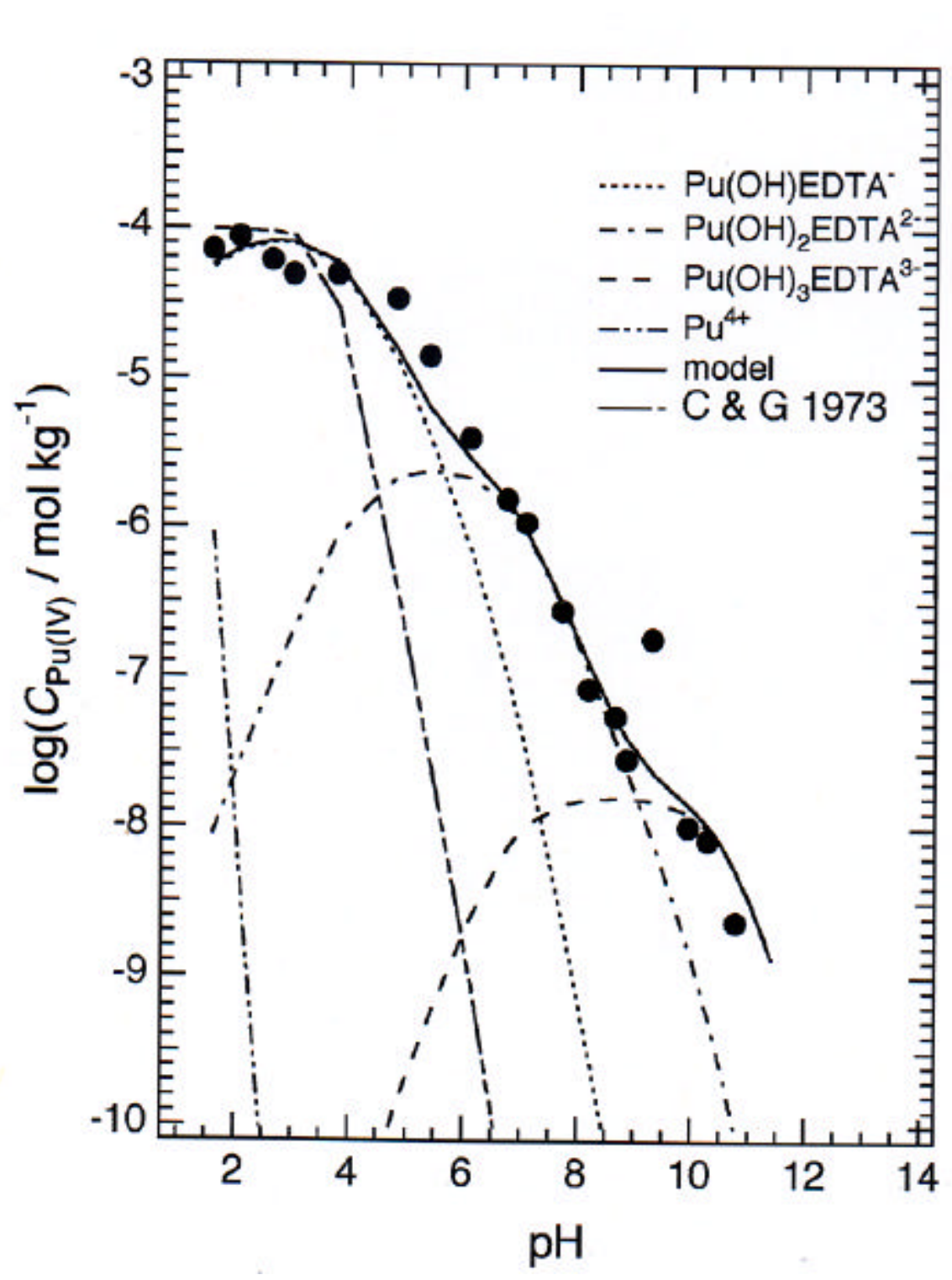

Figure 1. Aqueous $\mathrm{Pu}(\mathrm{IV})$ concentrations contacting $\mathrm{PuO}_{2}(\mathrm{am})$ suspensions in $0.0001 \mathrm{M}$ EDTA adjusted to a range in $\mathrm{pH}$ values and equilibrated for 7 days. Lines represent predicted total and species concentrations, as designated. Modeling species and parameters are reported in Tables 1 and 2. C\&G 1973 represents predicted concentrations based on PuEDTA(aq) complexation constant value reported by Cauchetier and Guichard 1973. 
Table 1. Dimensionless standard ${ }^{a}$ molar Gibbs free energies of formation () $\left.G_{f}^{0} / R T\right)$

\begin{tabular}{|c|c|c|}
\hline Species & ) $\mathrm{G}_{\mathrm{f}}^{0} / \mathrm{RT}$ & Reference \\
\hline $\mathrm{Pu}^{4+}$ & -194.279 & [Fuger and Oetting 1976] \\
\hline $\mathrm{Pu}(\mathrm{OH}) \mathrm{EDTA}^{-}$ & $-288.566 \pm 0.81$ & This study ${ }^{b}$ \\
\hline $\mathrm{Pu}(\mathrm{OH})_{2} \mathrm{EDTA}^{2-}$ & $-371.219 \pm 0.81$ & This study ${ }^{b}$ \\
\hline $\mathrm{Pu}(\mathrm{OH})_{3} \mathrm{EDTA}^{3-}$ & $-446.197 \pm 0.81$ & This study ${ }^{b}$ \\
\hline $\mathrm{PuO}_{2}(\mathrm{am})$ & -387.594 & [Rai 1984] \\
\hline $\mathrm{H}_{6} \mathrm{EDTA}^{2+}$ & -3.09 & This study, calculated $^{c}$ \\
\hline $\mathrm{H}_{5} \mathrm{EDTA}^{+}$ & -3.47 & This study, calculated $^{\mathrm{c}}$ \\
\hline $\mathrm{H}_{4} \operatorname{EDTA}(\mathrm{aq})$ & 0.00 & [Pokrovsky et al. 1998] \\
\hline $\mathrm{H}_{3} \mathrm{EDTA}^{-}$ & 5.76 & [Pokrovsky et al. 1998] \\
\hline $\mathrm{H}_{2} \mathrm{EDTA}^{2-}$ & 12.87 & [Pokrovsky et al. 1998] \\
\hline HEDTA $^{3-}$ & 28.71 & [Pokrovsky et al. 1998] \\
\hline EDTA $^{4-}$ & 53.05 & [Pokrovsky et al. 1998] \\
\hline $\mathrm{H}_{2} \mathrm{O}(\mathrm{B}$ & -95.663 & [Harvie et al. 1984] \\
\hline $\mathrm{OH}^{-}$ & -63.435 & [Harvie et al. 1984] \\
\hline $\mathrm{Na}^{+}$ & -105.651 & [Harvie et al. 1984] \\
\hline $\mathrm{Cl}^{-}$ & -52.955 & [Harvie et al. 1984] \\
\hline
\end{tabular}

a. The values for all species involving EDTA are only relative to each other, calculated with the assumption that $\mathrm{H}_{4} \mathrm{EDTA}(\mathrm{aq})=0.0$.

b. Based on 7-day equilibration period data for 0.0001 M EDTA set (Table A.1).

c. Calculated from $\log \mathrm{K}_{\mathrm{n}}$ values reported by Krot et al. [1962], using the Davies equation to extrapolate the values to zero ionic strength and combining this information with other data reported in this table. Although these species were included for completeness, they do not significantly impact the calculations reported in this paper. 
Table 2. Pitzer ion-interaction parameters used in this study ${ }^{\mathrm{a}}$

\begin{tabular}{|c|c|c|c|c|c|}
\hline \multicolumn{6}{|c|}{ Binary parameters } \\
\hline Species & $\$^{(0)}$ & $\$^{(1)}$ & $\$^{(2)}$ & $C^{\mathrm{N}}$ & Reference \\
\hline $\mathrm{Pu}^{4+}-\mathrm{Cl}^{-}$ & 1.644 & 15.5 & 0.00 & 0.1 & $\mathrm{~b}$ \\
\hline $\mathrm{Na}^{+}-\mathrm{EDTA}^{4-}$ & 1.016 & 11.60 & 0.00 & 0.001 & $\begin{array}{c}\text { [Pokrovsky et al. } \\
\text { 1998] }\end{array}$ \\
\hline $\mathrm{Na}^{+}-\mathrm{HEDTA}^{3+}$ & 0.5458 & 5.22 & 0.00 & -0.048 & $\begin{array}{c}\text { [Pokrovsky et al. } \\
1998]\end{array}$ \\
\hline $\mathrm{Na}^{+} \mathrm{H}_{2} \mathrm{EDTA}^{2-}$ & -0.1262 & 1.74 & 0.00 & 0.054 & $\begin{array}{c}\text { [Pokrovsky et al. } \\
1998]\end{array}$ \\
\hline $\mathrm{Na}^{+} \mathrm{H}_{3} \mathrm{EDTA}^{-}$ & -0.2345 & 0.29 & 0.00 & 0.059 & $\begin{array}{c}\text { [Pokrovsky et al. } \\
1998]\end{array}$ \\
\hline $\mathrm{Na}^{+}-\mathrm{OH}^{-}$ & 0.0864 & 0.253 & 0.00 & 0.0044 & [Harvie et al. 1984] \\
\hline $\mathrm{Na}^{+}-\mathrm{Cl}^{-}$ & 0.0765 & 0.2664 & 0.00 & 0.00127 & [Harvie et al. 1984] \\
\hline $\mathrm{H}^{+}-\mathrm{C} 1^{-}$ & 0.1775 & 0.2945 & 0.00 & 0.0008 & [Harvie et al. 1984] \\
\hline \multicolumn{6}{|c|}{ Ternary parameters } \\
\hline $\mathrm{H}^{+}-\mathrm{Na}^{+}$ & 0.036 & & & & [Harvie et al. 1984] \\
\hline $\mathrm{H}^{+}-\mathrm{Na}^{+}-\mathrm{Cl}^{-}$ & -0.004 & & & & [Harvie et al. 1984] \\
\hline $\mathrm{Cl}^{-}-\mathrm{OH}^{-}$ & -0.05 & & & & [Harvie et al. 1984] \\
\hline $\mathrm{Cl}^{-}-\mathrm{OH}^{-}-\mathrm{Na}^{+}$ & -0.006 & & & & [Harvie et al. 1984] \\
\hline
\end{tabular}

a. Because the chloride concentrations in most of the samples are low, primarily from the $\mathrm{HCl}$ used in adjusting $\mathrm{pH}$ values, the parameters involving $\mathrm{Cl}^{-}$do not figure significantly in calculations, but were included in the model for completeness.

b. Based on analogy to corresponding U(IV) system [Rai et al. 1997]. 
chemistry. Because of this paucity of data specifically for $\mathrm{Pu}(\mathrm{V})$, it is generally accepted that $\mathrm{Np}(\mathrm{V})$ can be used as an analog for $\mathrm{Pu}(\mathrm{V})$. However, more extensive verification of this concept over a wide range of conditions is desirable.

The objectives of this study were to determine the solubility of $\mathrm{PuO}_{2}(\mathrm{am})$ in air-equilibrated suspensions, where $\mathrm{Pu}(\mathrm{V})$ is known to be the dominant oxidation state (Rai et al. 1980a, Rai 1984) over a range of $\mathrm{NaCl}$ and $\mathrm{NaClO}_{4}$ concentrations and to determine whether the ion-interaction parameters for $\mathrm{Np}(\mathrm{V})$ with $\mathrm{Cl}$ or $\mathrm{ClO}_{4}{ }^{-}$reported in the literature (Neck et al. 1995) can be used to reliably predict the corresponding $\mathrm{Pu}(\mathrm{V})$ behavior. The goal is to verify the extent to which $\mathrm{Np}(\mathrm{V})$ can be used as an analog for $\mathrm{Pu}(\mathrm{V})$ in studies of the speciation and environmental modeling of $\mathrm{Pu}$. Two different methods were used to analyze the data. One method used estimated values of the pe, and the other assumed constant effective oxygen fugacities. The results from both of these methods show that $\mathrm{Pu}(\mathrm{V})$ indeed does behave in an analogous fashion to $\mathrm{Np}(\mathrm{V})$.

\section{Significant Results}

The aqueous $\mathrm{Pu}$ concentrations in contact with $\mathrm{PuO}_{2}(\mathrm{am})$ suspensions at different concentrations of $\mathrm{NaClO}_{4}$ or $\mathrm{NaCl}$ (with the exception of $4.36 \mathrm{~m} \mathrm{NaCl}$ ) are similar at the different equilibration periods (Figures 2 and 3), indicating that the steady-state concentrations are reached rapidly. The observed increase in Pu concentration with the increase in equilibration period for the 4.36 $\mathrm{m} \mathrm{NaCl}$ system is not due to slow kinetics of dissolution of $\mathrm{PuO}_{2}(\mathrm{am})$, but rather is due to oxidative dissolution as a result of the production of oxidizing species by alpha radiolysis in the chloride media. The experimental data indicate that the dominant aqueous $\mathrm{Pu}$ oxidation state is $\mathrm{Pu}(\mathrm{V})$.

Ion-interaction parameters for the bulk electrolyte ions in this study are available (Table 3), but they are not available for $\mathrm{PuO}_{2}{ }^{+}$. However, parameters for $\mathrm{NpO}_{2}{ }^{+}$(which is used often as an analog for $\mathrm{PuO}_{2}^{+}$) with $\mathrm{Cl}$ and $\mathrm{ClO}_{4}^{-}$, are available (Neck et al. 1995) and were used to compare how closely these $\mathrm{NpO}_{2}{ }^{+}$parameters, in conjunction with $\log \mathrm{K}^{0}$ value of -18.85 (similar to -19.45 reported by Rai 1984) for the reaction $\left[\mathrm{PuO}_{2}(\mathrm{am})=\mathrm{PuO}_{2}{ }^{+}+\mathrm{e}^{-}\right]$along with the estimated pe values, described the $\mathrm{PuO}_{2}{ }^{+}$system. Close agreement exists between the predicted and observed $\mathrm{PuO}_{2}{ }^{+}$concentration in all of the systems investigated $\left(0.4\right.$ and $4.0 \mathrm{M} \mathrm{NaClO}_{4}$ or $\mathrm{NaCl}$; Figures 2 and 3), with the exception of a 110-day equilibration period for 4.0 M NaCl. Significant increases in solubility in $4.0 \mathrm{M} \mathrm{NaCl}$ observed at longer equilibration periods (Figure 3) are most likely due to conversion of $\mathrm{NaCl}$ to $\mathrm{NaOCl}$ through alpha radiolysis (Buppelmann et al 1988). The close agreement demonstrates that the modeling parameters (Table 3) used in this 

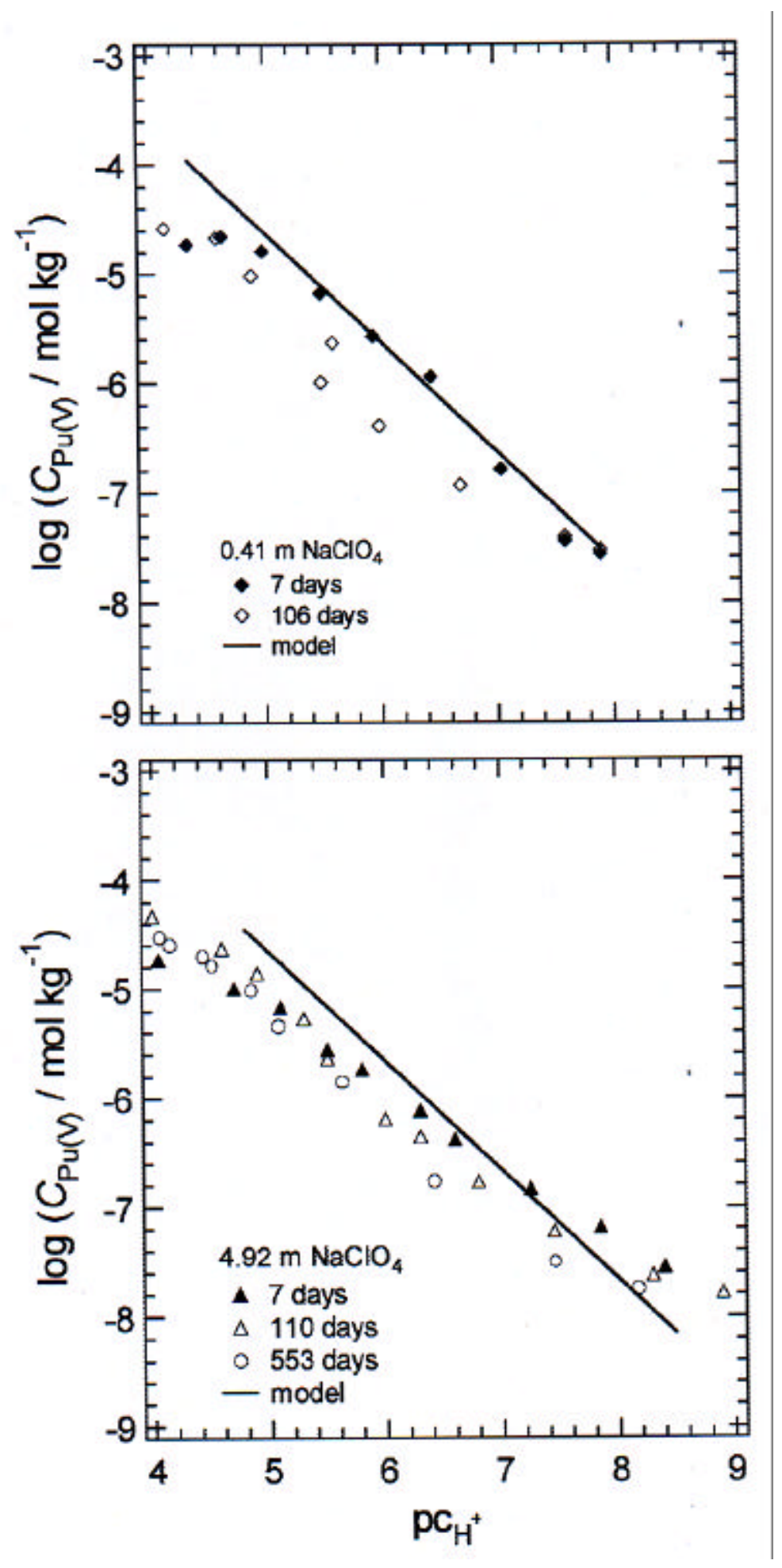

Figure 2. Plutonium concentrations in 0.0018-: $m$ filtrates from $\mathrm{PuO}_{2}(\mathrm{am})$ suspensions in $\mathrm{NaClO}_{4}$ and equilibrated for different periods. Solid line represents model predictions based on ion-interaction parameters reported in Table 3 and assumptions discussed in the text. 

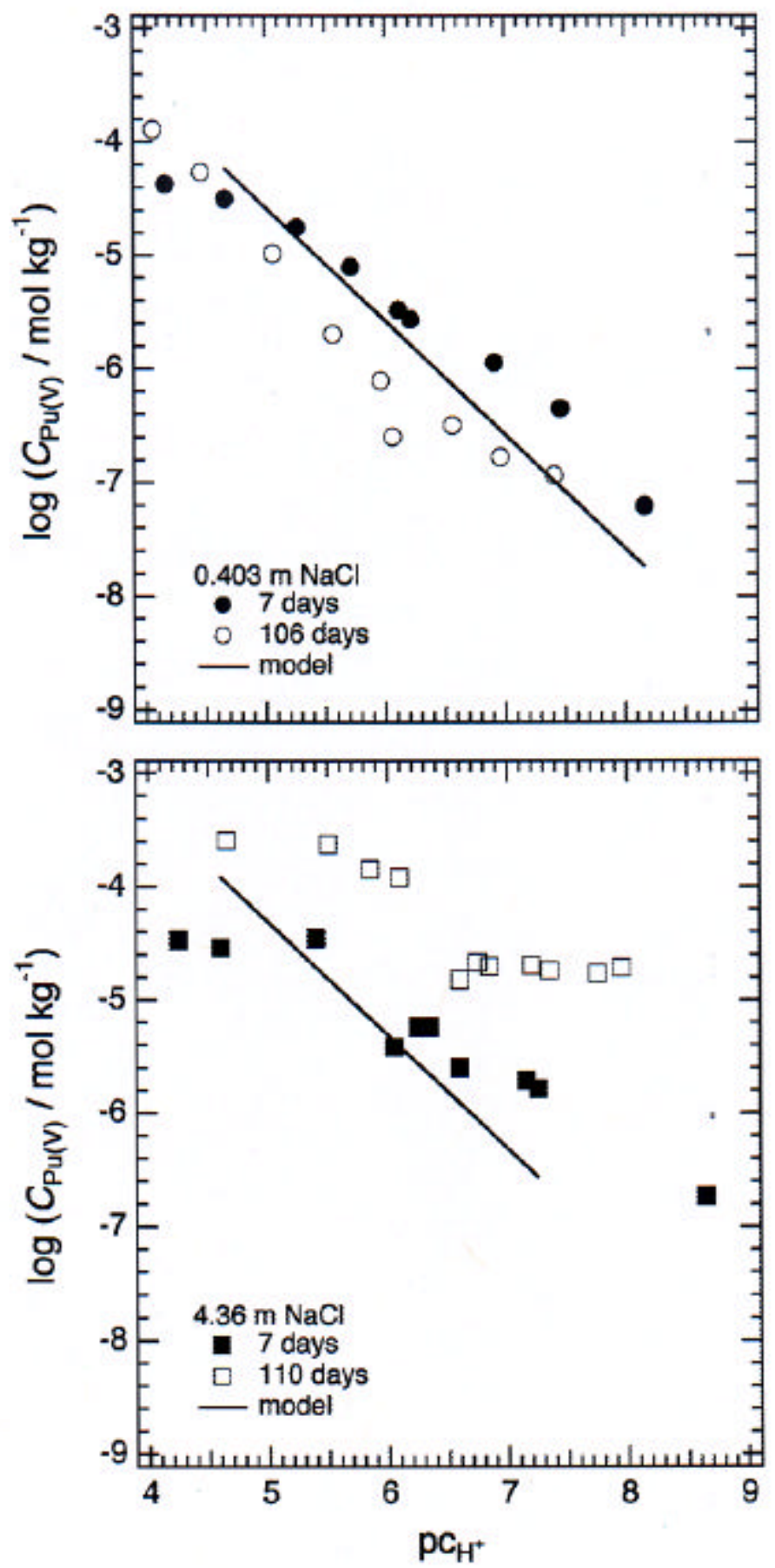

Figure 3. Plutonium concentrations in 0.0018-: $\mathrm{m}$ filtrates from $\mathrm{PuO}_{2}(\mathrm{am})$ suspensions in $\mathrm{NaCl}$ and equilibrated for different periods. Solid line represents model predictions based on ion-interaction parameters reported in Table 3 and assumptions discussed in the text. 
Table 3. Pitzer ion-interaction parameters used in this study.

\begin{tabular}{|c|c|c|c|c|c|}
\hline \multicolumn{6}{|c|}{ Binary parameters } \\
\hline Species & $\$^{(0)}$ & $\$^{(1)}$ & $\$^{(2)}$ & $\mathrm{C}^{\mathrm{N}}$ & Reference \\
\hline $\mathrm{Na}^{+}-\mathrm{Cl}^{-}$ & 0.0765 & 0.2644 & 0.00 & 0.00127 & Harvie et al. [1984] \\
\hline $\mathrm{Na}^{+}-\mathrm{ClO}_{4}^{-}$ & 0.0554 & 0.2755 & 0.00 & -0.00118 & Pitzer and Mayorga [1973] \\
\hline $\mathrm{Na}^{+}-\mathrm{OH}^{-}$ & 0.0864 & 0.2530 & 0.00 & 0.00440 & Harvie et al. [1984] \\
\hline $\mathrm{H}^{+}-\mathrm{Cl}^{-}$ & 0.1775 & 0.2945 & 0.00 & 0.00080 & Harvie et al. [1984] \\
\hline $\mathrm{H}^{+}-\mathrm{ClO}_{4}^{-}$ & 0.1747 & 0.2931 & 0.00 & 0.00819 & Pitzer and Mayorga [1973] \\
\hline $\mathrm{Ca}^{2+}-\mathrm{OH}^{-}$ & 0.1747 & -0.2303 & -5.72 & 0.00 & Harvie et al. [1984] \\
\hline $\mathrm{Ca}^{2+}-\mathrm{Cl}^{-}$ & 0.3159 & 1.614 & 0.00 & -0.00034 & Harvie et al. [1984] \\
\hline $\mathrm{PuO}_{2}^{+}-\mathrm{Cl}^{-}$ & 0.1415 & 0.2810 & 0.00 & 0.00 & This study ${ }^{\mathrm{a}}$ \\
\hline $\mathrm{PuO}_{2}^{+}-\mathrm{ClO}_{4}^{-}$ & 0.257 & 0.180 & 0.00 & 0.0081 & This study $^{\mathrm{a}}$ \\
\hline \multicolumn{6}{|c|}{ Common ternary parameters } \\
\hline Species & & & Value & & Reference \\
\hline $\mathrm{Na}^{+}-\mathrm{H}^{+}$ & & & 0.036 & & Harvie et al. [1984] \\
\hline $\mathrm{Na}^{+}-\mathrm{H}^{+}-\mathrm{Cl}^{-}$ & & & -0.004 & & Harvie et al. [1984] \\
\hline $\mathrm{Cl}^{-}-\mathrm{OH}^{-}$ & & & -0.050 & & Harvie et al. [1984] \\
\hline $\mathrm{Cl}^{-}-\mathrm{OH}^{-}-\mathrm{Na}^{+}$ & & & -0.006 & & Harvie et al. [1984] \\
\hline $\mathrm{Ca}^{2+}-\mathrm{H}^{+}$ & & & 0.092 & & Harvie et al. [1984] \\
\hline $\mathrm{Ca}^{2+}-\mathrm{H}^{+}-\mathrm{Cl}^{-}$ & & & -0.015 & & Harvie et al. [1984] \\
\hline $\mathrm{H}^{+}-\mathrm{Na}^{+}-\mathrm{ClO}_{4}^{-}$ & & & -0.016 & & Pitzer [1991] \\
\hline
\end{tabular}

a. Assumed to be identical to the corresponding $\mathrm{NpO}_{2}{ }^{+}$parameters reported by Neck et al. [1995] 
study are reasonable, and that the $\mathrm{NpO}_{2}{ }^{+}$ion interaction parameters with $\mathrm{Cl}$ and $\mathrm{ClO}_{4}{ }^{-}$are equally applicable to the corresponding $\mathrm{PuO}_{2}{ }^{+}$system. Changes in pe would increase or decrease the solubility curves up and down. However, the difference between the $\mathrm{PuO}_{2}{ }^{+}$concentrations in 0.4 and $4.0 \mathrm{M}$ solutions, the direction of change, and the shape of the curves depends on the aqueous species and the ion interaction parameters used in calculations. Therefore, a pe independent approach can be used to test how well the $\mathrm{Np}(\mathrm{V})$ parameters describe the observed $\mathrm{Pu}(\mathrm{V})$ behavior. Such analyses and the experimental data showed that: 1) the predicted concentrations in $4.0 \mathrm{M} \mathrm{NaCl}$ and $\mathrm{NaClO}_{4}$ solutions without the inclusion of parameters for $\mathrm{PuO}_{2}{ }^{+}$with $\mathrm{Cl}$ and $\mathrm{ClO}_{4}{ }^{-}$are approximately an order of magnitude higher than with the inclusion of these parameters; 2) the difference between the concentrations in 0.4 and 4.0 M solutions for the observed as well as for the predicted concentrations are similar; and 3) the inclusion of Pitzer ion-interaction parameters for $\mathrm{PuO}_{2}{ }^{+}$correctly predicts a decrease and an increase in observed $\mathrm{PuO}_{2}{ }^{+}$concentrations in $\mathrm{NaClO}_{4}$ and $\mathrm{NaCl}$ solutions, respectively, when the concentrations of the electrolytes were changed from 0.4 to $4.0 \mathrm{M}$. These results show that ion-interaction parameters for $\mathrm{PuO}_{2}{ }^{+}$with $\mathrm{Cl}$ and $\mathrm{ClO}_{4}{ }_{4}$ are required to accurately predict the effects of changes in the concentrations of the bulk electrolytes, and that the $\mathrm{NpO}_{2}{ }^{+}$ parameters can be used to model satisfactorily the $\mathrm{PuO}_{2}{ }^{+}$behavior.

In summary, the solubility of $\mathrm{PuO}_{2}(\mathrm{am})$ was determined in air-equilibrated suspensions as a function of $\mathrm{pH}$, time, and concentrations of $\mathrm{NaCl}$ or $\mathrm{NaClO}_{4}$. With the exception of $4.0 \mathrm{M} \mathrm{NaCl}$ at longer equilibration periods ( $\$ 106$ days), the data support $\mathrm{Pu}(\mathrm{V})$ as the dominant aqueous species in all of the systems investigated. In agreement with the data reported in the literature, $\mathrm{Pu}(\mathrm{VI})$ was a result of oxidants produced by alpha radiolysis and was found to be the dominant oxidation state only in 4.0 $\mathrm{M} \mathrm{NaCl}$ suspensions equilibrated for ca. 106 days. The predicted Pu concentrations, using available thermodynamic data and Pitzer ion-interaction parameters for $\mathrm{Np}(\mathrm{V})$ with $\mathrm{Cl}$ or $\mathrm{ClO}_{4}{ }^{-}$were in good agreement with the observed $\mathrm{Pu}$ concentrations as a function of $\mathrm{pc}_{\mathrm{H}+}$ for all of the systems investigated (synthetic WIPP brine, and 0.4 and $4.0 \mathrm{M} \mathrm{NaClO}_{4}$ and $\mathrm{NaCl}$ ). This confirms that $\mathrm{NpO}_{2}{ }^{+}$and $\mathrm{PuO}_{2}{ }^{+}$ systems behave in an analogous fashion.

It is also of value to develop the capability for predicting $\mathrm{PuO}_{2}(\mathrm{am})$ solubility behavior in geologic repositories. For this purpose, $\mathrm{PuO}_{2}(\mathrm{am})$ solubility was determined for samples under $\mathrm{N}_{2}$ (gas) atmosphere in a synthetic solution of which $5.31 \mathrm{~m} \mathrm{NaCl}$ is the major componant (described by Rao et al 1999) and which is representative of a brine from the Waste Isolation Pilot Project (WIPP). A close agreement exists between our predicted value, using the data in Table 1 in the above reference and 
other assumptions discussed in that paper, and the measured $\mathrm{Pu}$ concentrations $\left[\log \mathrm{C}_{\mathrm{pu}(\mathrm{V})} / \mathrm{mol} \mathrm{kg}^{-1}\right]$ values of -5.94 and -5.83 measured, and -5.93 and -5.78 predicted for $\mathrm{pc}_{\mathrm{H}+}$ values of 6.46 and 6.38 , respectively, indicating the usefulness of the model developed in this study for predicting $\mathrm{Pu}(\mathrm{V})$ behavior in repository environments.

A manuscript detailing the results of this study has been submitted to Radiochimica Acta. (Rai et al 2000b).

\section{$\underline{\text { III-3 Plutonium species with / without Reducing Agents }}$}

Reliable thermodynamic data for all the oxidation states of plutonium are required to develop comprehensive models for prediction of its behavior in different environments. The difficulty in obtaining reliable thermodynamic data for $\mathrm{Pu}(\mathrm{V})$ due to its redox and/or disproportionation reactions in aqueous systems has resulted in very limited data for $\mathrm{Pu}(\mathrm{V})$ chemistry.

The known stability of soluble $\mathrm{Pu}(\mathrm{V})$ in slightly acidic to near neutral solutions in which $\mathrm{PuO}_{2}(\mathrm{am})$ is suspended (Rai et al 1980, Rai 1984) was used to study the solubility of plutonium in 0.4 and $4.0 \mathrm{M} \mathrm{NaCl}$ or $\mathrm{NaClO}_{4}$ solutions ranging in $\mathrm{pcH}$ values from 4 to 9 as a function of time. The close agreement between the observed solubility and the predicted solubility using Pitzer ion-interaction parameters of $\mathrm{Np}(\mathrm{V})$ with $\mathrm{CI}$ or $\mathrm{ClO}_{4}{ }^{-}$indicates that $\mathrm{Pu}(\mathrm{V})$, as expected, behaves in an analogous fashion to $\mathrm{Np}(\mathrm{V})$ and confirms the value of using $\mathrm{Np}(\mathrm{V})$ data to model $\mathrm{Pu}(\mathrm{V})$ behavior.

Although $\mathrm{Pu}(\mathrm{V})$ is the dominant oxidation state in most natural waters (Nitsche et al 1984, Rai et al 2000b, Nelson and Lovett 1978, Nelson et al 1984, Bendietti and Trabalka 1980, Fukai et al 1987, Choppin and Stout 1989) there are reductants in many geologic environments that might reduce the $\mathrm{PuO}_{2}{ }^{+}$species to the tri- or tetravalent states. In redox studies, the reduction of $\mathrm{PuO}_{2}{ }^{+}$by hydrogen peroxide was measured to have an inverse dependence on the $\mathrm{H}^{+}$concentration with a half-life for reduction $\left(10^{-10} \mathrm{M} \mathrm{Pu}(\mathrm{V}), 0.001 \mathrm{M} \mathrm{H}_{2} \mathrm{O}_{2}\right)$ of about 8 days (Morgenstern and Choppin 1999). Similar studies showed a fast oxidation of $\mathrm{Pu}(\mathrm{IV})$ to $\mathrm{Pu}(\mathrm{V})$ and $\mathrm{Pu}(\mathrm{VI})$ by $\mathrm{MnO}_{2}$ : Since this may be an important factor in Pu redox in the tank wastes, measurement of the rate equation in high alkaline conditions could provide very useful data for evaluating the best remediation systems. Initial experiments with $\mathrm{NaOCl}$ (also present in tank wastes) confirmed that it oxidized $\mathrm{Pu}(\mathrm{IV})$ to $\mathrm{Pu}(\mathrm{V})$ and $\mathrm{Pu}(\mathrm{VI})$. 


\section{Detailed Results}

\section{IV-1 Th(IV) Complexation with Citrate and EDTA}

The high stability of the An(IV)EDTA and An(IV)DTPA complexes results in extremely small concentrations of free metal in solutions of excess ligand in solution $\left(<10^{-10} \mathrm{M}\right)$, so indirect competitive methods are necessary to measure the equilibrium concentrations in solution.

Citric acid (2-hydroxypropane-1, 2, 3-tricarboxylic acid was chosen as a competing ligand. Th(IV) was studied initially as an analog of Pu(IV) to avoid redox problems. Using literature values for the stability constants of the $\mathrm{Th}(\mathrm{Cit})_{\mathrm{n}}(\mathrm{n}=1-3)$ complexes (Raymond et al 1987) and thorium hydrolysis constants (Moon 1989), the speciation of solutions containing Th(IV), citric acid, and EDTA was calculated as a function of $\mathrm{pH}$. The speciation diagrams were generated using HySS with the results shown in Figure 4. The results of the speciation calculations indicate that citric acid should be able to compete effectively with Th(IV) for EDTA binding and can minimize hydrolysis of the free thorium cation. In addition, only two species, ThEDTA and $\mathrm{Th}(\mathrm{Cit})_{3}$, are predicted to be present in solution over the $\mathrm{pH}$ range of $6-8$.

The competitive equilibrium between citric acid and EDTA for Th(IV) complexation was

monitored by ${ }^{1} \mathrm{H}$ NMR spectroscopy as the ${ }^{1} \mathrm{H}$ NMR spectra of citric acid and EDTA are easily resolved. The ${ }^{1} \mathrm{H}$ NMR spectrum of free EDTA showed a downfield singlet corresponding to the eight acetate protons and an upfield singlet of the four ethylenic protons of the EDTA backbone. The citric acid ${ }^{1} \mathrm{H}$ NMR spectrum exhibited two doublets upfield of the ethylenic singlet of free EDTA. Based upon the symmetry of the molecule, the ${ }^{1} \mathrm{H}$ NMR spectrum of citric acid would be expected to exhibit a single singlet corresponding to the protons of the three acetate groups. However, a pair of doublets was observed which we assign to hindered rotation of the acetate groups. No variation in the ${ }^{1} \mathrm{H}$ NMR spectra of citrate anion was observed as function of $\mathrm{pH}$.

The formation of ThEDTA and $\mathrm{Th}(\mathrm{Cit})_{3}$ in solution resulted in changes in the observed ${ }^{1} \mathrm{H}$ NMR spectra. The singlets due to the acetate and ethylenic groups of EDTA shifted upfield. The resonance due to the acetate proton showed further splitting, the extent of which depends upon the degree of metal 
binding. The ethylenic resonance remained a singlet. The ${ }^{1} \mathrm{H}$ NMR of citric acid was broadened by complexation with thorium, but no new resonances attributable to $\mathrm{Th}(\mathrm{Cit})_{\mathrm{n}}$ were evident.

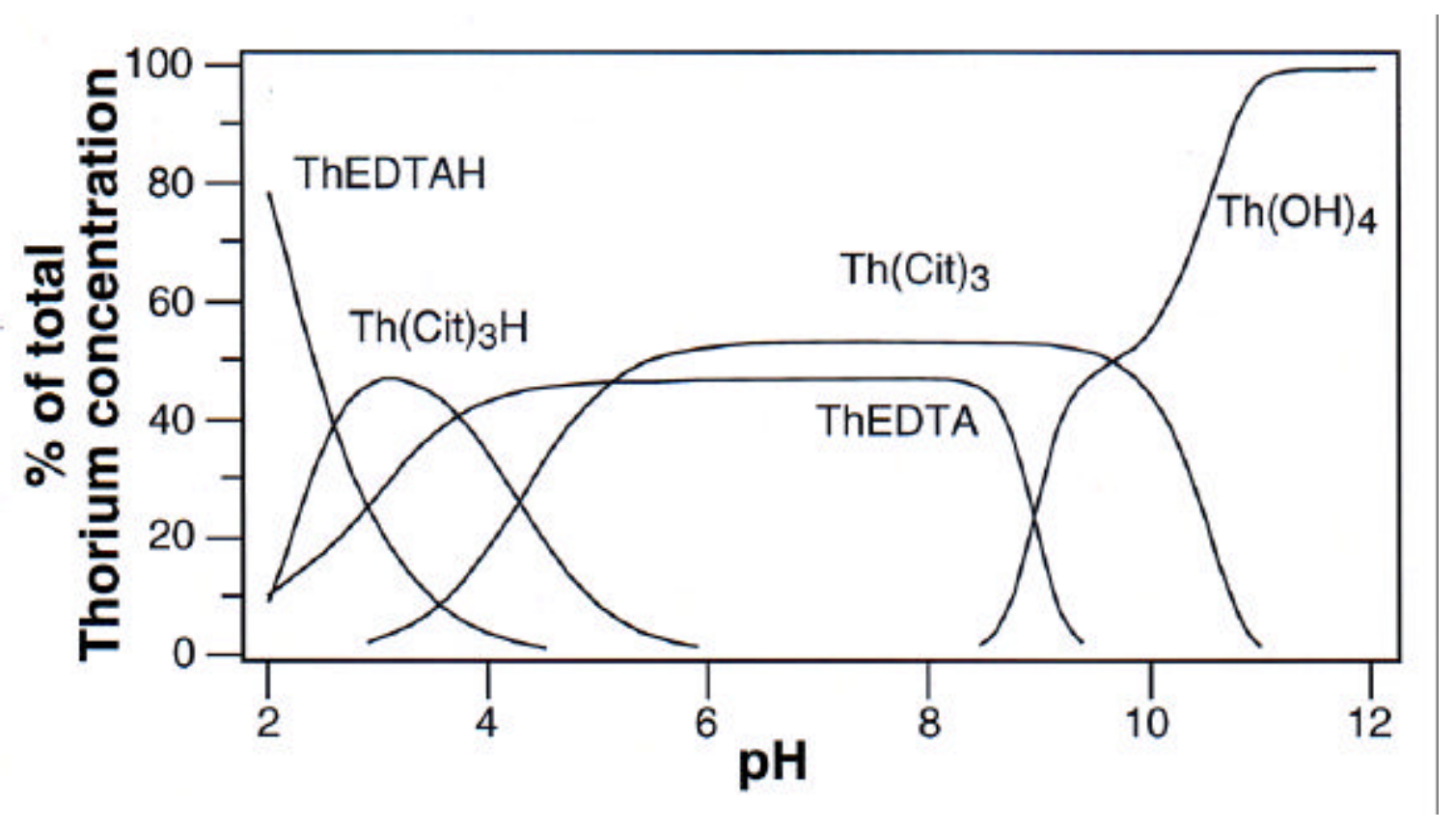

Figure 4. Th(IV)-Citrate-EDTA, I = $0.1 \mathrm{M}$. 
The concentration of ThEDTA in the competition experiments was determined by integration of the singlet, due to the ethylenic protons of the bound EDTA and of the free EDTA. The Th(Cit $)_{\mathrm{n}}$ stability constants have been determined at $\mathrm{I}=0.1 \mathrm{~m} \mathrm{NaCl}, 0.3 \mathrm{~m} \mathrm{NaCl}, 0.5 \mathrm{~m} \mathrm{NaCl}$, and $1.0 \mathrm{~m} \mathrm{NaCl}$, 3.0 $\mathrm{NaCl}$ by potentiometric titration. The $\mathrm{Th}(\mathrm{Cit})_{\mathrm{n}}$ stability constants calculations were performed by independent analysis of the data by BEST and Hyperquad2000. The values are presented in Table 4.

The Th-EDTA stability constant was determined by using the citrate anion as a competing ligand at $\mathrm{pcH}=6.0$. From the calculation of speciation using estimated constants, at $\mathrm{pH}=6.0$ only ThEDTA and $\mathrm{Th}(\mathrm{Cit})_{3}$ have significant concentrations in solution. The magnitude of the Th-EDTA stability constant was calculated using the equation:

$$
\beta_{\text {ThEDTA }}=\beta_{\text {Th(cit })_{3}} \frac{[\text { ThEDTA }][\text { cit }]^{3}}{\left[\text { Th }(\text { cit })_{3}\right][\text { EDTA }]}
$$

where $\left[\right.$ ThEDTA] is calculated from the concentration of free EDTA determined by ${ }^{1} \mathrm{H}$ NMR and the total mass balance for EDTA and citric acid, and [Th(Cit $\left.)_{3}\right]$ is assumed equal to [EDTA]. The stability constants calculated using the above equation are listed in Table 4 as a function of ionic strength.

A publication reporting these results is in preparation.

\section{$\underline{\text { IV-2 Solubility measurements of } \mathrm{PuO}_{2}} \underline{\text { (am) }}$}

Another set of solubility experiments involved samples of samples of $\mathrm{PuO}_{2}(282.5 \mathrm{~g} / \mathrm{L})$ stirred in 0.40 and $4.00 \mathrm{M}$ solutions of $\mathrm{NaCl}$ and of $\mathrm{NaClO}_{4}$ over a $\mathrm{pH}$ range of 3 to 10 . The samples were centrifuged and analyzed for $\mathrm{pH}$, Eh, and plutonium oxidation state distribution, as described previously. Because the studies were conducted in air and over a very large range in $\mathrm{pH}$ values, extending to the alkaline region, we calculated the importance of hydroxo and/or carbonato complexes of $\mathrm{PuO}_{2}{ }^{+}$in these solutions. Modeling (Pitzer) calculations, assuming (a) hydroxo and carbonato complexes and (b) the ion-interaction parameters for the $\mathrm{Np}(\mathrm{V})$ system apply to the $\mathrm{Pu}(\mathrm{V})$ system, showed that the hydroxo and carbonato complexes of $\mathrm{PuO}_{2}{ }^{+}$contribute much less than $1 \%$ to the total soluble $\mathrm{Pu}$, and, therefore, these complexes need not be included in the final model. 
Table 4. Stability constants of Th-Citrate and Th-EDTA at complexes at $25 \mathrm{C}$

\begin{tabular}{|c|c|c|c|c|c|c|}
\hline & \multicolumn{5}{|c|}{ a. Th-Cit } & \multirow[t]{2}{*}{ Th-EDTA } \\
\hline Ionic & & & & & & \\
\hline Strength (m) & $\log \$_{101}$ & $\log \$_{102}$ & $\log \$_{112}$ & $\log \$_{103}$ & $\log \$_{113}$ & $\log \$_{101}$ \\
\hline $0.1 \mathrm{NaCl}$ & $11.66 \pm 0.09$ & $20.89 \pm 0.18$ & $23.79 \pm 0.18$ & $26.26 \pm 0.18$ & $30.52 \pm 0.19$ & $22.8 \pm 0.5$ \\
\hline $0.3 \mathrm{NaCl}$ & $11.53 \pm 0.05$ & $20.35 \pm 0.02$ & $22.56 \pm 0.04$ & $25.45 \pm 0.06$ & $29.39 \pm 0.07$ & $22.0 \pm 0.3$ \\
\hline $0.5 \mathrm{NaCl}$ & $10.12 \pm 0.05$ & $19.19 \pm 0.02$ & $21.42 \pm 0.04$ & $24.32 \pm 0.04$ & $28.43 \pm 0.04$ & $20.6 \pm 0.7$ \\
\hline $1.0 \mathrm{NaCl}$ & $9.46 \pm 0.37$ & $19.13 \pm 0.01$ & $21.70 \pm 0.01$ & $24.15 \pm 0.03$ & $28.50 \pm 0.02$ & $20.7 \pm 0.3$ \\
\hline $3.0 \mathrm{NaCl}$ & $15.81 \pm 0.14$ & $22.43 \pm 0.08$ & $* * * *$ & $25.59 \pm 0.13$ & $30.95 \pm 0.04$ & $22.1 \pm 0.1$ \\
\hline
\end{tabular}


Significant increases in solubility in $4.0 \mathrm{M} \mathrm{NaCl}$ were observed at longer equilibration periods. These increases are most likely due to conversion of $\mathrm{NaCl}$ to $\mathrm{NaOCl}$ through alpha radiolysis. Although the measured redox potentials in these systems may not be reliable, the increases in pe values at the 110day equilibration period as compared with a 7-day period for $4 \mathrm{M} \mathrm{NaCl}$ and 7- and 106-day equilibration periods for $0.4 \mathrm{M} \mathrm{NaCl}$ are consistent with the above conclusion. In the presence of this $\mathrm{NaOCl}, \mathrm{Pu}(\mathrm{VI})$ would be the stable oxidation state, which would account for the high aqueous $\mathrm{Pu}$ concentrations. Spectrophotometric analyses of the dissolved solids from 4.0 M NaCl suspensions equilibrated for 425 days showed the presence of $\mathrm{Pu}(\mathrm{VI})$ and the absence of other oxidation states. The increase in pe, the presence of $\mathrm{Pu}(\mathrm{VI})$ at longer equilibration periods, and the observed increases in $\mathrm{pc}_{\mathrm{H}+}$ are consistent with published data (Buppelmann et al 1988). Because of the lack of information on the solid phases and the aqueous species in these concentrated chloride solutions equilibrated for long periods, further interpretation of these results is not possible. It is also important to note that the effects of radiolysis can be complicated and are dependent upon the ionic media. For example: 1) the formation of $\mathrm{Pu}(\mathrm{VI})$, and an increase in pe and solubility were observed in $4.0 \mathrm{M} \mathrm{NaCl}$, but were not observed in $\mathrm{NaClO}_{4}$ solutions of similar ionic strength, even at long equilibration times, (553 days); 2) for $\mathrm{PuO}_{2}(\mathrm{am})$ suspensions in concentrated $\mathrm{Cl}$, an increase in $\mathrm{pc}_{\mathrm{H}+}$ and the production of $\mathrm{NaOCl}$ were observed; for $\mathrm{PuO}_{2}(\mathrm{am})$ suspensions in $0.0015 \mathrm{M} \mathrm{CaCl}$, a continuous decrease in $\mathrm{pH}$ was observed with increasing in equilibration time which is probably due to radiolytic oxidation of dissolved nitrogen to $\mathrm{HNO}_{3}$.

\section{$\underline{\text { IV-3 } \mathrm{PuO}^{+}} \underline{2} \underline{\text { Reduction by } \mathrm{H}_{2}} \underline{\underline{\mathrm{O}_{2}}}$}

In this area of the research program, we studied the kinetics of the reduction of pentavalent plutonium, $\mathrm{PuO}_{2}{ }^{+}$by hydrogen peroxide, which is known to be a product of radiolysis in high-level liquid wastes and which may influence the oxidation state of plutonium in such wastes (Sullivan 1983). There is also evidence for the formation of hydrogen peroxide through photolysis of organic matter in surface waters (Cooper and Zika 1983), (Zika et al 1985). As Pu(V) is the predominant oxidation state of dissolved plutonium in natural waters (Choppin et al 1986), (Orlandini et al 1986), (Choppin 1991), the interaction between $\mathrm{PuO}_{2}{ }^{+}$and hydrogen peroxide may be major importance in the environmental behavior of plutonium. Our review of relevant journals failed to find any studies of the redox kinetics of tracer level $\mathrm{PuO}_{2}{ }^{+}$with hydrogen peroxide in alkaline media. 
In this study a combined ultrafiltration and solvent extraction procedure using TTA as extractant was employed to monitor the change in plutonium oxidation state with time. This method was found to be relatively simple and fast, allowing experimental data points to be recorded within short time intervals. The major disadvantage of this method lies in the necessity to change the solution $\mathrm{pH}$ from its original value between, 7.9 and 10.8, to $\mathrm{pH} 4.5$ prior to ultrafiltration and solvent extraction. Such changes possibly can perturb the oxidation state distribution in solution. Consequently, a second independent solvent extraction procedure using dibenzoylmethane, DBM, as an extractant was used to validate the experimental results. This procedure allows separation of $\mathrm{Pu}(\mathrm{III})$ and $\mathrm{Pu}(\mathrm{VI})$ from $\mathrm{Pu}(\mathrm{IV})$ and $\mathrm{Pu}(\mathrm{V})$ without changing the sample $\mathrm{pH}$ but it does require more time between data points, (Figure 5).

Based on the experimental data the rate equation for the reduction of $\mathrm{Pu}(\mathrm{V})$ with hydrogen peroxide can be described by:

$$
\begin{gathered}
\mathrm{R}=-\mathrm{d}[\mathrm{Pu}(\mathrm{V})] / \mathrm{dt} \\
=\mathrm{k}[\mathrm{Pu}(\mathrm{V})]^{1} \mathrm{q}\left[\mathrm{H}_{2} \mathrm{O}_{2}\right]^{\mathrm{m}} \mathrm{q}\left[\mathrm{H}^{+}\right]^{-\mathrm{n}}
\end{gathered}
$$

A dependence of the apparent first-order rate constant on the reciprocal of the proton concentration indicates a correlation between the reduction rate and the deprotonation of the reducing agent, hydrogen peroxide. This observation suggests the formation of $\mathrm{PuO}_{2}{ }^{+}-\mathrm{O}_{2} \mathrm{H}^{-}$in an activated complex.

Assuming first order kinetics with respect to the concentration of $[\mathrm{Pu}(\mathrm{V})]$, the reduction of $\mathrm{PuO}_{2}^{+}$by hydrogen peroxide can be described by the following rate equations:

$$
\mathrm{R}=\left(3.59 \times 10^{-9} \pm 1.79 \times 10^{-9}\right) \mathrm{min}^{-1} \mathrm{q}[\mathrm{Pu}(\mathrm{V})] \mathrm{q}\left[\mathrm{H}_{2} \mathrm{O}_{2}\right] \mathrm{q}\left[\mathrm{H}^{+}\right]^{-1}
$$

Using this equation, the redox half-life of $\mathrm{Pu}(\mathrm{V})$ under various conditions can be calculated. In seawater conditions at $\mathrm{pH} 8.0$ with a typical concentration of hydrogen peroxide of $1.0 \times 10^{-7} \mathrm{M}, 50 \%$ of the pentavalent plutonium is reduced within approximately 55 years. In waste storage tanks, however, $\mathrm{pH}$ values are sometimes higher and the concentration of hydrogen peroxide might reach higher levels due to water radiolysis. Under these conditions, the redox half-life of $\mathrm{Pu}(\mathrm{V})$ would be shortened significantly; e.g., at pH 11 and in presence of millimolar levels of hydrogen peroxide, it decreases to 4 min. (Figure 6). 
These results are reported in an article in Radiochimica Acta, $\underline{86}$, pp. 109-113 (1999).

a

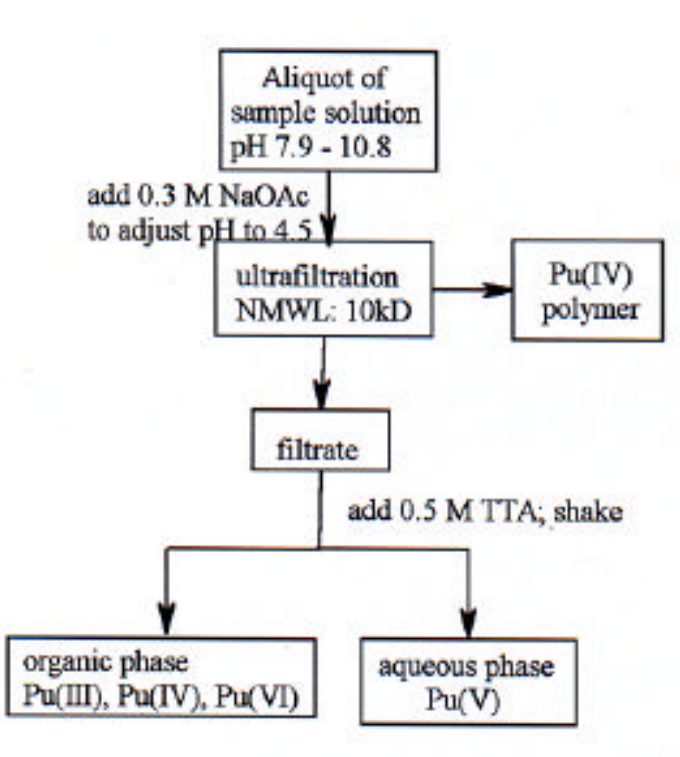

$\mathrm{b}$

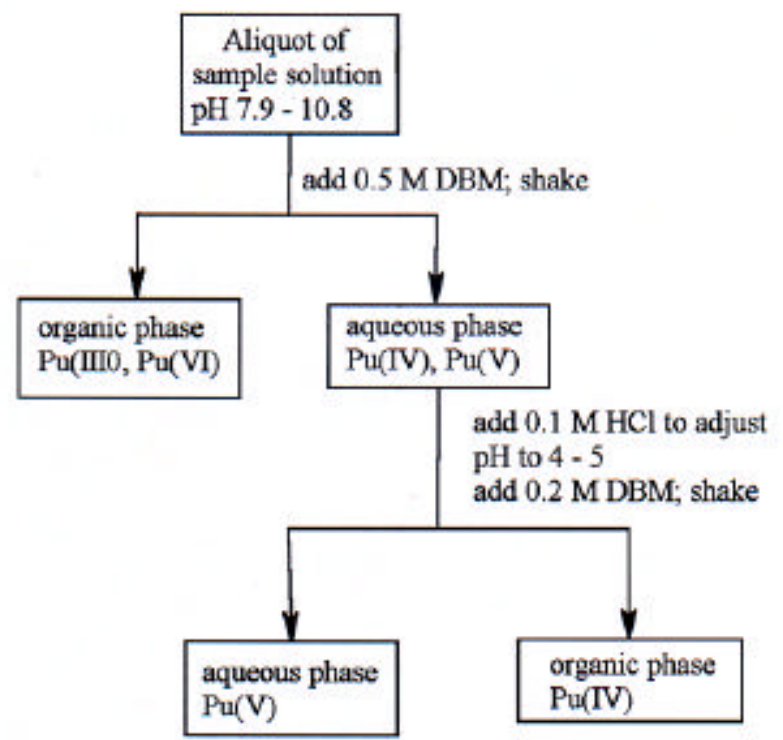

Figure 5. (a) Combined ultrfiltration and TTA extraction procedure for plutonium oxidation state analysis.

(b) DBM procedure for plutonium oxidation state analysis. 
The kinetics of oxidation of $\mathrm{Pu}(\mathrm{IV})$ by manganese dioxide has been investigated. $\mathrm{MnO}_{2}$ is a component in some of the tank wastes of the USDOE and is also a common component of natural waters. Consequently, it may contribute to the kinetics of oxidation of $\mathrm{Pu}(\mathrm{IV})$ to the more soluble $\mathrm{PuO}_{2}{ }^{+}$and $\mathrm{PuO}_{2}{ }^{2+}$ species. The same techniques used in the studies of oxidation by $\mathrm{H}_{2} \mathrm{O}_{2}$ were employed. A set of data on the oxidation state distribution of plutonium after 7 days reaction with varying amounts of a suspension $\mathrm{MnO}_{2}$ at $\mathrm{pH} 8.1$ are given in Table 5 .

In acid solution ( $\mathrm{pH} 2.0 \mathrm{~B} 3.5$ ), the rate equation was found to be:

$$
\mathrm{R}=-\mathrm{d}[\mathrm{Pu}(\mathrm{IV})] / \mathrm{dt}=3.72( \pm 0.13) \mathrm{q} 10^{-3}[\mathrm{Pu}(\mathrm{IV})] \mathrm{q}\left[\mathrm{MnO}_{2}\right] \mathrm{q}\left[\mathrm{H}^{+}\right]^{-0.21}
$$

Experiments in neutral $\mathrm{pH}$ range showed rapid oxidation kinetics but a lower fraction of oxidized species, due to strong hydrolysis and stabilization of tetravalent state. The conclusion is that $\mathrm{MnO}_{2}$ may contribute to remobilization of $\mathrm{Pu}(\mathrm{IV})$ through oxidation to more soluble and mobile $\mathrm{Pu}(\mathrm{V})$ and $\mathrm{Pu}(\mathrm{VI})$.

A manuscript on this study is in the final stage of preparation. A poster was presented at the $\mathrm{Pu}$ Futures B 2000 Conference (Santa Fe, N.M., 7/00).

\section{$\underline{\text { IV-5 Pu(IV) Oxidation by } \mathrm{NaOCl}}$}

The oxidation of $\mathrm{Pu}(\mathrm{IV})$ to higher states by $\mathrm{NaOCl}$ was also investigated. As noted earlier in this Report, $\mathrm{OCI}$ is formed in aqueous saline systems by radiolyses. It has been reported (Buppleman et al 1988) that hypochlorite oxidizes $\mathrm{Pu}(\mathrm{IV})$ to $\mathrm{Pu}(\mathrm{VI})$ but no data on rates or intermediates are available. Since $\mathrm{OCI}$ would be present in stored radioactive wastes or in environmental waters subjected to radiation, its quantitative effect on $\mathrm{Pu}(\mathrm{IV})$ redox speciation is an important question in such systems.

The kinetics of the oxidation of $\mathrm{Pu}(\mathrm{IV})$ with sodium hypochlorite were investigated in the $\mathrm{pH}$ range 7.7-8.3 in 1.0 $\mathrm{M} \mathrm{NaNO}_{3}$. The oxidation state distribution of plutonium was monitored by two parallel extraction steps using TTA and HDEHP as extractants. The oxidation of Pu (IV) by sodium hypochlorite was found to proceed to $\mathrm{Pu}(\mathrm{V})$ and $\mathrm{Pu}(\mathrm{VI})$, with the relative amounts of oxidized species being dependent on the concentration of sodium hypochlorite. The stability of $\mathrm{Pu}(\mathrm{VI})$ in the presence of sodium hypochlorite was studied in separate experiments. 


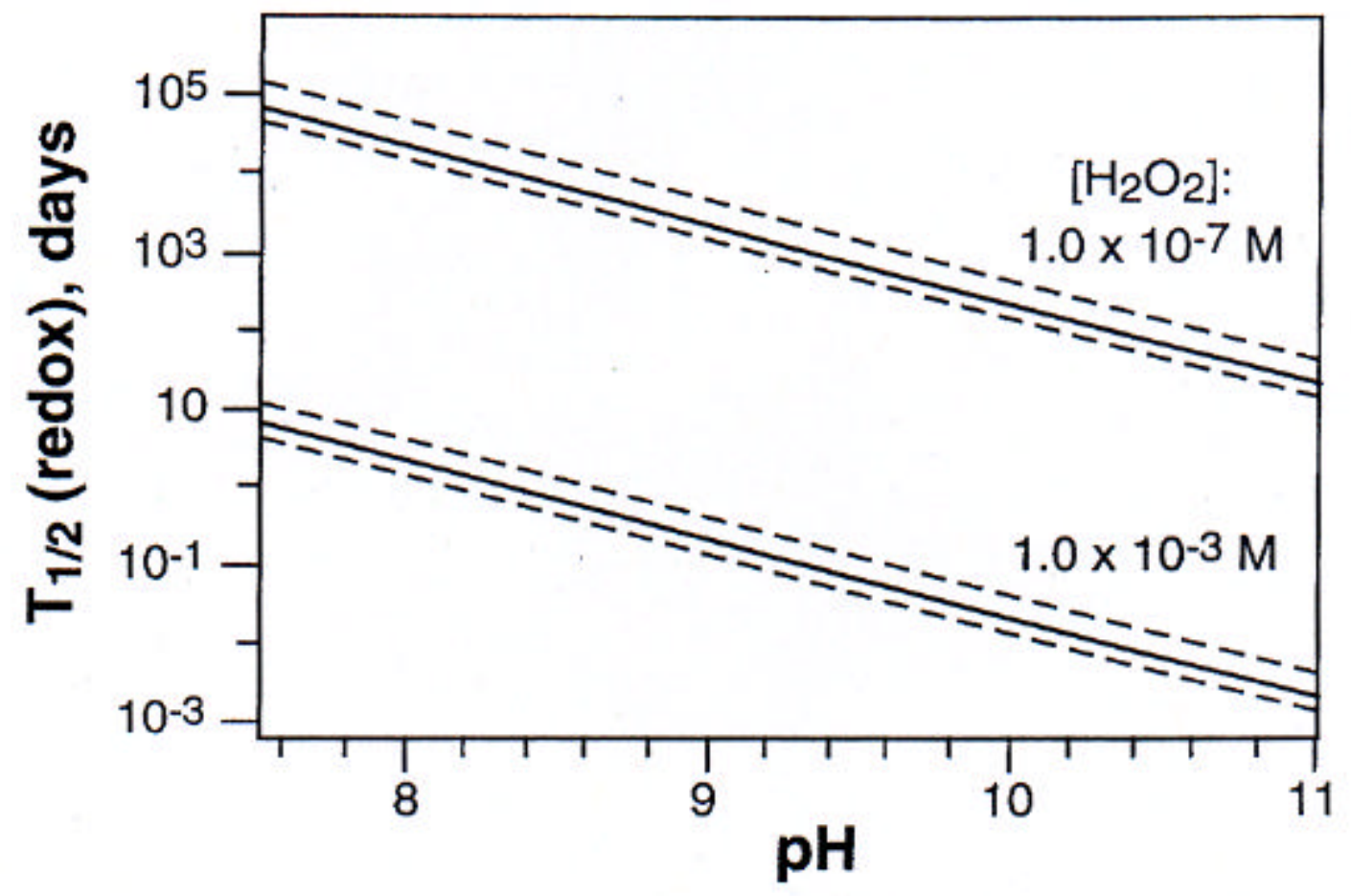

Figure 6. $\mathrm{T}_{1 / 2}$ of reduction of $\mathrm{PuO}_{2}^{+}$by peroxide as a function of $\mathrm{pH}$. 
Table 5. Oxidation of $\mathrm{Pu}(\mathrm{IV})$ by $\mathrm{MnO}_{2(5)}: \mathrm{pH} 8.1, \mathrm{t}=7$ days

\begin{tabular}{ccccc}
\hline $\begin{array}{c}\mathrm{MnO}_{2} \\
(\mathrm{mmoles} / \mathrm{L})\end{array}$ & $\begin{array}{c}{[\mathrm{Pu}(\mathrm{IV})]} \\
(\%)\end{array}$ & $\begin{array}{c}{[\mathrm{Pu}(\mathrm{V})]} \\
(\%)\end{array}$ & $\begin{array}{c}{[\mathrm{Pu}(\mathrm{VI})]} \\
(\%)\end{array}$ & $\begin{array}{c}\mathrm{k}= \\
\left(10^{4} \mathrm{~min}^{-1}\right)\end{array}$ \\
\hline- & $86.2 \pm 0.1$ & $7.2 \pm 1.1$ & $6.6 \pm 1.0$ & - \\
$9.58 \mathrm{q} 10^{-3}$ & $69.6 \pm 0.8$ & $15.7 \pm 0.8$ & $14.7 \pm 1.1$ & $8.39 \pm 1.80$ \\
$2.05 \mathrm{q} 10^{-2}$ & $72.3 \pm 2.3$ & $20.4 \pm 2.7$ & $7.4 \pm 1.0$ & - \\
$5.15 \mathrm{q} 10^{-2}$ & $61.6 \pm 0.5$ & $28.0 \pm 0.4$ & $10.5 \pm 0.1$ & - \\
$5.14{\mathrm{q} 10^{-1}}^{5}$ & $54.6 \pm 1.7$ & - & - & - \\
1.02 & 51.4 & - & - & - \\
4.97 & $50.1 \pm 1.2$ & - & - & - \\
\hline
\end{tabular}


The reaction reaches a stable oxidation state distribution of plutonium after ca. 2 days for higher concentration of $\mathrm{NaOCl}(0.02 \mathrm{M})$ but requires longer times for lower concentrations. The oxidation of $\mathrm{Pu}(\mathrm{IV})$ with $0.02 \mathrm{M} \mathrm{NaOCl}$ at $\mathrm{pH} 8.2$ leads to the formation of $27 \% \mathrm{Pu}(\mathrm{IV}), 21 \% \mathrm{Pu}(\mathrm{V})$ and $52 \%$ after 12 days. Decreasing the concentration of sodium hypochlorite to the submillimolar concentration range decreases the amount of oxidized species formed. The relative amounts of $\mathrm{Pu}(\mathrm{IV}),(\mathrm{V})$ and (VI) formed after 2 days are summarized in Table 6. Since the rate of the oxidation reaction is relatively fast, the reaction rates could not be evaluated by these techniques.

Addition of $\mathrm{Pu}(\mathrm{VI})$ to a solution containing $0.02 \mathrm{M} \mathrm{NaOCL}$ resulted in a fast decrease of the concentration of $\mathrm{Pu}(\mathrm{VI})$ to $\mathrm{ca} .47 \%$ of its initial concentration while $22 \% \mathrm{Pu}(\mathrm{V})$ and $31 \% \mathrm{Pu}(\mathrm{IV})$ were formed. The observed oxidation state distribution resembles very closely the results for identical experimental conditions in which, initially, $\mathrm{Pu}(\mathrm{VI})$ was added. These results indicate that the sam e equilibrium distribution of oxidation states is obtained, regardless of the original oxidation state, $\mathrm{Pu}(\mathrm{IV})$ or $\mathrm{Pu}(\mathrm{VI})$, that is added to the solution.

Lowering the concentration of sodium hypochlorite to $10^{-4} \mathrm{M}$ resulted in an even sharper drop in the concentration of $\mathrm{Pu}(\mathrm{VI})$. The amount of $\mathrm{Pu}(\mathrm{VI})$ present was reduced to ca. $11 \%$ of its initial concentration within 1 hour. Only $10 \% \mathrm{Pu}(\mathrm{V})$ was formed while $\mathrm{Pu}(\mathrm{IV})$ constituted the predominant oxidation state, with a relative concentration of nearly $80 \%$. Again, these results are comparable to the results summarized in column 1 of Table 6, where, starting with $\mathrm{Pu}(\mathrm{IV})$ a similar oxidation state distribution was obtained in the presence of $1.6 \mathrm{q}^{-4} 0^{-4} \mathrm{M} \mathrm{NaOCl}$ after 2 days reaction time.

In summary, hypochlorite oxidizes $\mathrm{Pu}(\mathrm{IV})$ to $\mathrm{Pu}(\mathrm{V})$ and $\mathrm{Pu}(\mathrm{VI})$ with the fraction of these oxidation states increasing (at fixed time) with the $\mathrm{OCI}$ concentration. However, at these concentrations and $\mathrm{pH}$, the systems reach an equilibrium state in which all three states are present after several (2-12) days.

It is planned to prepare a manuscript on this system. A poster was presented at Pu Futures 2000 Conference (Santa Fe, 7/00). 
Table 6: Oxidation of $\mathrm{Pu}(\mathrm{IV})$ with various concentrations of sodium hypochlorite; Relative fractions of $\mathrm{Pu}(\mathrm{IV}), \mathrm{Pu}(\mathrm{V})$ and $\mathrm{Pu}(\mathrm{VI})$ after 2 days reaction time.

\begin{tabular}{lccccc}
\hline$[\mathrm{NaOCl}](\mathrm{mol} / \mathrm{L})$ & $1.0 \times 10^{-4}$ & $1.6 \times 10^{-4}$ & $3.2 \times 10^{-4}$ & $7.8 \times 10^{-4}$ & $2.0 \times 10^{-2}$ \\
\hline$[\mathrm{Pu}(\mathrm{IV})](\%)$ & 7.9 & 64 & 57 & 52 & 30 \\
{$[\mathrm{Pu}(\mathrm{V})](\%)$} & 10 & 22 & 20 & 22 & 22 \\
{$[\mathrm{Pu}(\mathrm{VI})](\%)$} & 11 & 14 & 24 & 26 & 48 \\
\hline
\end{tabular}




\section{$\underline{\text { V. References }}$}

Bondietti, E.A., Travalka, J.R.: Evidence for $\mathrm{Pu}(\mathrm{IV})$ in an alkaline freshwater pond. Radiochem, Radioanal. Lett., 42, 169-176 (1980).

Cauchetier, P., Guichard, C.: Electrochemical and Spectrophotometric Study of the Complexes of Plutonium Ions with EDTA. I. Plutonium(III) and (IV). Radiochim. Acta 19, 137-146 (1973).

Champ, D.R., Robertson, D.E.: Chemical Speciation of Radionuclides in Contaminant Plumes at the Chalk River Nuclear Laboratories. In: Speciation of Fission and Activation Products in the Environment (Bulman, R.A., Cooper, J.R., eds.) Elsevier, New York 1986.

Choppin, G.R., Roberts, R.A., Morse, J. W.: Effects of Humic Substances on Plutonium Speciation in Marine Systems. In Organic Marine Geochemistry, M.L. Sohn, ed., ACS Symposium Series, 382-388 (1986).

Choppin, G.R. Stout, B.E.: Actinide Behavior in Natural Waters. Sci. of the Total Environ. 83, 203-216 (1989).

Choppin, G.R.: Redox Speciation of Plutonium in Natural Waters. J. Radioanal. and Nucl. Chem., 147, 109-116 (1991).

Choppin, G.R., Rao, L.F.: Reduction of Neptunium(VI) by Organic Compounds. In: L.R. Morss and J. Fuger (eds.), Transuranium Elements, A Half Century, The American Chemistal Society, 262-275 (1992).

Choppin, G.R.: Actinide Behavior in Neutral Media. Symposium for EMSP at the $218^{\text {th }}$ Meeting of the American Chemical Society, New Orleans, August 22-26, in press as Am. Chem. Soc. book (1999). 
Cleveland, J.M., Rees, T.F.: Characterization of Plutonium in Maxey Flats Radioactive Trench Leachates. Science 212, 1506-1509 (1981).

Foreman, J.K., Smith, T.D.: The Nature and Stability of the Complex Ions Formed by Ter-, Quadri, and Sexa-Valent Plutonium Ions with Ethylenediaminetetraacetic Acid. Part I. pH Titrations and Ion-Exchange Studies. J. Chem. Soc. (Part 1), 1752-1758 (1957a).

Foreman, J.K., Smith, T.D.: The Nature and Stability of the Complex Ions Formed by Ter-, Quadri, and Sexa-Valent Plutonium Ions with Ethylenediaminetetraacetic Acid (EDTA). Part II. Spectroscopic Studies. J. Chem. Soc. (Part 2), 1758-1762 (1957b).

Fuger, J., Oetting, F.L.: The Chemical Thermodynamics of Actinide Elements and Compounds: Part 2, The Actinide Aqueous Ions. IAEA, Vienna (1976).

Fukai, R., Yamoto, A, Thain, M., Bilinski, H.: Oxidation States of Fallout Plutonium in Mediterranean Rain and Seawater. J. Geochem., 21, 51-57 (1987).

Harvie, C.E., Mфler, N., Weare, J.H.: The Prediction of Mineral Solubilities in Natural Waters: The Na-K-Mg-Ca-H-Cl- $\mathrm{SO}_{4}-\mathrm{OH}-\mathrm{HCO}_{3}-\mathrm{CO}_{2}-\mathrm{H}_{2} \mathrm{O}$ System to High Ionic Strengths at 25 C. Geochim. Cosmochim. Acta 48, 723 (1984).

Killey, R.W.D., McHugh, J.O., Champ, D.R., Cooper, E.L., Young, J.L.: Subsurface Cobalt-60 Migration from a Low Level Waste Disposal Site. Environ. Sci. Technol. 18, 148-157 (1984).

Klygin, A.E., Smirnova, I.D., Nikol=skaya, N.A.: The Solubility of Ethylenediaminetetraacetic Acid in Ammonia and Hydrochloric Acid and Its Reaction with Uranium(IV) and Plutonium(IV). Russian Journal of Inorganic Chemistry 4(12), 12791282 (1959). 
Krot, N.N., Ermolaev, N.P., Gel=man, A.D.: The Behavior of Ethylenediaminetetraacetic Acid in Acid Solutions and Its Reaction with Uranium(IV). Russ. J. Inorg. Chem. 7(9), 1062-1066 (1962).

Means, J.L., Crerar, D.A., Duguid, J.O.: Migration of Radioactive Wastes: Radionuclide Mobilization by Complexing Agents. Science 200, 1477-1486 (1978).

Moon, H.: Equilibrium Ultrafiltration of Hydrolyzed Thorium(IV) Solutions, Bull. Korean Chem. Soc. 10, 270 (1989).

Neck, V., Fanghänel, T.H., Rudolph, G., Kim, J.I.: Thermodynamics of Neptunium(V) in Concentrated Salt Solutions: Chloride Complexation and Ion Interaction (Pitzer) Parameters for the $\mathrm{NpO}_{2}{ }^{+}$Ion, Radiochim. Acta 69, 39 (1995).

Nelson, D.M., Lovett, M.B.: Oxidation State of Plutonium in the Irish Sea. Nature, 276, 599-601 (1978).

Nelson, D.M., Carey, A.E., Bowen, V.T.: Plutonium Oxidation State Distributions in the Pacific Ocean During 1980-1981. Earth Planet Sci. Lett., 68, $422-430$ (1984).

Nitsche, H., Becraft, K.: The Complexation Behavior of Neptunium and Plutonium with Nitrilotriacetic Acid. In: Morss, L.R. and Fuger, J. (eds), Transuranium Elements, A Half Century. The American Chemical Society, 276-287 (1992).

Orlandini, K.A., Penrose, W.R., Nelson, D.M.: Pu(V) as the Stable Form of Oxidized Plutonium in Natural Waters. Mar. Chem. 18, 49 (1986).

ORNL: Integrated Data Base Report 1993: U.S. Spent Nuclear Fuel and Radioactive Waste Inventories, Projections, and Characteristics. Oak Ridge National Laboratory, Oak Ridge, Tennessee. 
Pitzer, K.S.: Activity Coefficients in Electrolyte Solutions, $2^{\text {nd }}$ ed., CRC Press, Boca Raton, 75-153 (1991).

Pokrovsky, O.S., Bronikowski, M.G., Moore, R.C., Choppin, G.R.: Interaction of Neptunyl(V) and Uranyl(VI) with EDTA in $\mathrm{NaCl}$ Media: Experimental Study and Pitzer Modeling. Radiochim. Acta 83, 23-29 (1998).

Rai, D., Serne, R.J., Swanson, J.L.: Solution Species of Plutonium in the Environment, J. Environ. Qual. 9, 417 (1980).

Rai, D.: Solubility Product of Pu(IV) Hydrous Oxide and Equilibrium Constants of $\mathrm{Pu}(\mathrm{IV}) / \mathrm{Pu}(\mathrm{V}), \mathrm{Pu}(\mathrm{IV}) / \mathrm{Pu}(\mathrm{VI})$, and $\mathrm{Pu}(\mathrm{V}) / \mathrm{Pu}(\mathrm{VI})$ Couples. Radiochim. Acta 35, 97-108 (1984).

Rai, D., Felmy, A.R., Sterner, S.M., Moore, D.A., Mason, M.J., Novak, C.F.: The Solubility of Th(IV) and U(IV) Hydrous Oxides in Concentrated $\mathrm{NaCl}$ and $\mathrm{MgCl}$ Solutions. Radiochim. Acta 79, 239-247 (1997).

Rai, D., Bolton, H., Moore, D.A., Hess, N.J., Choppin, G.R.: Thermodynamic Model for the Solubility of $\mathrm{PuO}_{2}(\mathrm{am})$ in the Aqueous $\mathrm{Na}^{+}-\mathrm{H}^{+}-\mathrm{OH}^{+}-\mathrm{Cl}^{\mathrm{B}} \mathrm{H}_{2} \mathrm{O}$ Ethylenediaminetetraacetate System, Radiochim. Acta (submitted 2000a)

Rai, D., Rao, L., Felmy, A.R., Moore, D.A., Choppin, G.R., Moore, R.C.: Thermodynamics of

$\mathrm{PuO}_{2}{ }^{+}-\mathrm{Na}^{+}-\mathrm{Cl}^{\mathrm{B}} \mathrm{ClO}_{4}{ }^{\mathrm{B}} \mathrm{OH}^{\mathrm{B}} \mathrm{H}_{2} \mathrm{O}$ System: Use of $\mathrm{NpO}_{2}{ }^{+}$Pitzer Ion Interaction Parameters for $\mathrm{PuO}_{2}^{+}$. Radiochim. Acta (in press 2000b).

Rai, D., Bolton, H., Moore, D.A., Hess, N.J., Choppin, G.R.: Thermodynamic Raymond, D.P., Duffield, J.R., Williams, D.R.: Complexation of Plutonium and Thorium in Aqueous Environments, Inorg. Chim. Acta 140, 309 (1987). 
Rao, L., Rai, D., Felmy, A.R., Novak, C.F.: Solubility of $\mathrm{NaNd}\left(\mathrm{CO}_{3}\right)_{2} \cdot 6 \mathrm{H}_{2} \mathrm{O}(\mathrm{c})$ in Mixed Electrolyte $\left(\mathrm{Na}-\mathrm{Cl}-\mathrm{CO}_{3} \mathrm{HCO}_{3}\right)$ and Synthetic Brine Solutions. In: Actinide Speciation in High Ionic Strength Media (Reed et al, ed.), Kluwer Academic/Plenum Publishers, New York (1999).

Riley, R.G., Zachara, J.M., Wobber, F.J.: Chemical Contaminants on DOE Lands and Selection of Contaminant Mixtures for Subsurface Science Research, DOE/ER-0547T. National Technical Information Service, U.S. Department of Commerce, Springfield, Virginia (1992). 
1. Mathur, J. N., Choppin, G.R. Paraffin Wzx-TOPO an Extractant for Actinides and Lanthanides. Solv. Extr. Ion Exch. 16, 739-749 (1998).

2. Rai, D., Bolton, H., Moore, D.A., Hess. N.J., and Choppin, G.R., Thermodynamic Model for the Solubility of $\mathrm{PuO}_{2}(\mathrm{am})$ in the Aqueous $\mathrm{Na}=-\mathrm{h}^{+}-\mathrm{OH}^{-}-\mathrm{Cl}^{-}-\mathrm{H}_{2} \mathrm{O}-$ ethylenediaminetetraacetate System; Radiochim. Acta, in press.

3. Rai, D., Moore, Felmy, R.A., Choppin, G.R., and Moore, R.C., Thermodynamics of the $\mathrm{PuO}_{2}{ }^{+}-\mathrm{Na}^{+}-\mathrm{OH}^{-}-\mathrm{Cl}-\mathrm{ClO}_{4}{ }^{-}-\mathrm{H}_{2} \mathrm{O}$ System: Use of $\mathrm{NpO}_{2}{ }^{+}$Pitzer Parameters for $\mathrm{PuO}_{2}{ }^{+}$; Radiochim. Acta, in press

4. Morgenstern, A., and Choppin, G. R.: Kinetics of the reduction of $\mathrm{Pu}(\mathrm{V}) \mathrm{O}_{2}{ }^{+}$Hydrogen Peroxide. Radiochim. Acta 86, 109-113 (1999)

5. Choppin, G. R.: Actinide Behavior in Neutral Media. Symposium for EMSP at the $218^{\text {th }}$ Meeting of the American Chemical Society, New Orleans, August 22-26, 1999, in press as Am. Chem. Soc. book.

6. Choppin, G.R., and Morgenstern, A.: Radionuclide Separations in Radioactive Wastes Disposal. J. Radioanal. Nucl. Chem. 243(1), 45-51 2000.

7. Choppin, G.R., and Morgenstern, A.: Distribution and Movement of Environmental Plutonium. Environmental Radioactivity Series 1, (2000) in press.

8. Choppin, G.R., and Morgenstern, A.: Kinetics of the Oxidation of Pu (IV) by $\mathrm{MnO}_{2}$, Radiochin Acta, submitted.; Also in Abstracts, Pu Futures-2000 Intern. Conference, Santa Fe, N.M., 2000.

9. Choppin, G.R., and Peterman, D.R.,: Applications of Lunainescence Spectroscopy to Solution Studies of Coordination Chemisty (Invited Paper), Coordination Chem. Rev., 174, 283-299 (1998).

10. Choppin, G.R., and Morgenstern, A., Kinetics of the Oxidation of Pu(IV) by $\mathrm{NaOCl}$, in preparation.; Also in Abstracts, Pu Futures-2000 Intern. Conference, Santa Fe, N.M., 2000. 


\section{Personnel}

\section{$\underline{1996-2000}$}

A. Principal Investigators.

Professor Gregory R. Choppin, Lawton Distinguished Professor of Chemistry, Florida State University.

Dr. Dhapat Rai, Senior Staff Scientist, Pacific Northwest National Laboratory.

B. Research Scientists (PNNL)

Drs. H. Bolton, D. A. Moore, N. J. Hess, R. A. Felmy

C. Post-Doctoral Research Associates (FSU)

Dr. Kath Morris, Ph.D., U. Manchester (England), presently, Lecturer, Leeds University (England).

Dr. Alfred Morgenstern, Ph.D., U. of Munich (Germany); presently, Research Chemist, Tranuranium Institute, Karlsruke (Germany).

Dr. Dean R. Peterman, Ph. D., U. of Cincinnati, presently, Research Scientist at Idaho Nation engineering Energy Laboratory.

Dr. J. N. Mathur, Visiting Scientist (2 mos), Behabba Atom. Energy Res. Center, India

D. Research Affliate

Dr. Robert C. Moore, Sandia National Laboratory. 